\title{
Identification of Continental Wetlands Using Different Orbital Remote Sensors
}

\author{
Identificação de zonas úmidas continentais usando diferentes \\ sensores orbitais remotos
}

\section{Identificación de humedales continentales utilizando diferentes sensores orbitales remotos}

\author{
Isadora Taborda Silva \\ https:/ / orcid.org/0000-0001-9053-4329 \\ isah.taborda@gmail.com \\ Universidade Federal de Mato Grosso do Sul, \\ UFMS, Campo Grande, MS \\ Jéssica Rabito Chaves \\ https:/ / orcid.org/0000-0003-2763-3361 \\ je.rabitochaves@gmail.com \\ Universidade Federal de Mato Grosso do Sul, \\ UFMS, Campo Grande, MS \\ Helen Rezende de Figueiredo \\ https:/ / orcid.org/0000-0002-6580-8305 \\ helenrezende.bio@gmail.com \\ Universidade Federal de Mato Grosso do Sul, \\ UFMS, Campo Grande, MS \\ Bruno Silva Ferreira \\ https:/ / orcid.org/0000-0002-0697-2834 \\ bsferreira@outlook.com \\ Universidade Federal de Mato Grosso do Sul, \\ UFMS, Campo Grande, MS \\ César Claudio Cáceres Encina \\ https:/ / orcid.org/0000-0001-8061-9804 \\ ccaceres.encina@gmail.com \\ Universidade Federal de Mato Grosso do Sul, \\ UFMS, Campo Grande, MS
}

Dhonatan Diego Pessi

https:/ / orcid.org/0000-0003-0781-785X

dhonatan.pessi@gmail.com

Universidade Federal de Rondonópolis, UFR, Rondonópolis, MT

Normandes Matos da Silva

https:/ / orcid.org/0000-0002-4631-9725

normandes32@gmail.com

Universidade Federal de Rondonópolis, UFR, Rondonópolis, MT

Eliane Guaraldo

https:/ / orcid.org/0000-0003-2526-1293

eliane.guaraldo@gmail.com

Universidade Federal de Mato Grosso do Sul, UFMS, Campo Grande, MS

Antonio Conceição Paranhos Filho https:/ / orcid.org/0000-0002-9838-5337 toni.paranhos@gmail.com Universidade Federal de Mato Grosso do Sul, UFMS, Campo Grande, MS 


\begin{abstract}
This paper evaluates the potential of false-color composite images, from 3 different remote sensing satellites, for the identification of continental wetlands. Landsat 8, Sentinel-2, and CBERS-4 scenes from three different Ramsar sites (i.e., sites designated to be of international importance) two sites located within the MatoGrossense Pantanal, and one within the Sul-mato-grossense were used for analyses. For each site, images from both the dry and rainy seasons were analyzed using NearInfrared (NIR), Shortwave Infrared (SWIR), and visible (VIS) bands. The results show that false-color composite images from both the Landsat 8 and the Sentinel-2 satellites, with both SWIR 2-NIR-BLUE and NIR-SWIR-RED spectral band combinations, allow the identification of wetlands.
\end{abstract}

Keywords: False-color composite imagery, multispectral sensor, Pantanal, photo interpretation, Ramsar sites.

Resumo: Este artigo avalia o potencial de imagens compostas de cores falsas, de 3 satélites diferentes de sensoriamento remoto, para a identificação de zonas úmidas continentais. Foram utilizadas para análise as cenas Landsat 8, Sentinel-2 e CBERS-4 de três locais diferentes de Ramsar (isto é, locais designados como de importância internacional) dois locais localizados no Pantanal Mato-Grossense e um no Pantanal Sul-mato-grossense para análise. Para cada local, as imagens das estações seca e chuvosa foram analisadas usando bandas de infravermelho próximo (NIR), infravermelho de ondas curtas (SWIR) e visível (VIS). Os resultados mostram que imagens compostas de cores falsas dos satélites Landsat 8 e Sentinel-2, com combinações de bandas espectrais SWIR 2-NIR-BLUE e NIR-SWIR-RED, permitem a identificação de áreas úmidas.

Palavras-chave: Imagens compostas em cores falsas, sensor multiespectral, Pantanal, interpretação de fotos, sites Ramsar.

Resumen: Este artículo evalúa el potencial de imágenes compuestas de colores falsos, de 3 satélites de teledetección diferentes, para la identificación de humedales continentales. Para el análisis se utilizaron escenas Landsat 8, Sentinel-2 y CBERS-4 de tres ubicaciones diferentes en Ramsar (es decir, ubicaciones designadas como de importancia internacional), dos ubicaciones ubicadas en el Pantanal Mato-Grossense y una en el Pantanal Sul-Mato-grossense para análisis. Para cada ubicación, las imágenes de las estaciones seca y lluviosa se analizaron utilizando infrarrojo cercano (NIR), infrarrojo de onda corta (SWIR) y bandas visibles (VIS). Los resultados muestran que las imágenes compuestas de colores falsos de los satélites Landsat 8 y Sentinel-2, con combinaciones de bandas espectrales SWIR 2-NIR-BLUE y NIR-SWIR-RED, permiten la identificación de áreas húmedas.

Palabras-clave: Imágenes compuestas en colores falsos, sensor multiespectral, Pantanal, interpretación fotográfica, sitios Ramsar

\title{
INTRODUCTION
}

Loss of wetlands is extensive with $>70 \%$ estimated to have been destroyed or compromised by human action since the early 20 ${ }^{\text {th }}$ century (Ozesmi \& Bauer, 2002; Nicholls, 2004; Gardner et al., 2015). Located in the Upper Paraguay Basin, Brazil, the Pantanal is the largest tropical wetland in the world, covering approximately 140,000 km² (Adámoli, 1986).

Its drought and flood cycles make the Pantanal a dynamic ecosystem. Due to the low incidence of precipitation, the waters found there originate from the surrounding river basins, with varying intensities, as well as the specific compositions of landscape units. 
Thus, its wetlands or floodplains are highly diverse and occupy transition zones between higher and well-drained environments and environments that remain constantly flooded (Owen \& Chiras, 1998).

Despite its importance, the region has been suffering from anthropic actions, causing significant loss of native vegetation and the consequent increase in pasture areas (Paranhos Filho, Moreira, Oliveira, Pagotto \& Mioto, 2014; Peres, Mioto, Marcato Junior \& Paranhos Filho, 2016). Understanding the nature of this wetland ecosystem is critical to maintaining its balance and mitigating potential anthropogenic threats. To improve wetland protection, understanding the dynamics of floods and identifying effective methods for describing and monitoring them is critical.

However, wetland areas are difficult to monitor due to their relative inaccessibility and seasonally dynamic nature (Hewes, 1951; Lee \& Lunetta, 1996; Mitch \& Gosselink, 2007). Remote sensing is an efficient and practical method that can be used to identify landscape distribution of wetlands over a large area with advantages including multispectral and multitemporal data collection (Ozesmi \& Bauer, 2002; Rundquist, Gitelson, Derry, Ramirez, Stark, \& Keydan, 2001). Furthermore, makes it possible to reliably analyze and monitor the Pantanal, which is vital for the preservation of the area (Santos, Pereira, Shimabukuro \& Rudorff, 2009; Paranhos Filho, Moreira, Oliveira, Pagotto \& Mioto, 2014; Guo, Li, Sheng, Xu \& Wu, 2017). Multispectral sensors are particularly useful because their multiple spectral bands allow many different band combinations for false-color composite images, which allow visualization of wavelengths beyond the visible spectrum. Different false-color composite images can be used to highlight different features and thus help to identify different targets.

Different sensors have already been used to identify the spatial distribution of different land cover and vegetation characteristics of the many habitats present in the Pantanal complex system. Evans and Costa (2013) use in their study multi-temporal L-band ALOS/ PALSAR, C-band RADARSAT-2, and ENVISAT/ ASAR data to map ecosystems and create a lake distribution map of the Lower Nhecolândia subregion in the Brazilian Pantanal, achieving a satisfactory result showing the spatial distribution of aquatic, terrestrial and transitional habitats.

The most suitable band combination and resulting false-color composite image varies for different targets, making it necessary to analyze which false-color composite provides the best target distinction of the studied object. Besides, since understanding the different spectral resolutions is the main factor influencing the recognition of different types of ground cover (Paranhos Filho, Moreira, Oliveira, Pagotto \& Mioto, 2014), it is important to identify the spectral behavior of each band to be used, as well as to understand the capabilities and limitations of each sensor.

This study aims to analyze the potential for individualization of the continental wetlands and compares different selected orbital sensors. It's intended to establish possible spectral response patterns. 


\section{MATERIALS AND METHODS}

\section{Study area}

Located in central South America and mostly covering Brazilian territory, the Pantanal is characterized by a tropical climate, with a monomodal flood pulse that varies in intensity from year to year, and well-defined dry and rainy seasons (Adámoli, 1986). It consists of an extensive sediment accumulation plain that, due to its low slope relief, is annually flooded by the Paraguay River and its tributaries during the rainy season (Adámoli, 1986; Penatti, 2014).

While the PantanaI complex can be divided into multiple sub-regions with very different characteristics, it can generally be divided into three groups based on water availability: approximately $10 \%$ to $20 \%$ is permanently covered by water or flooded for long periods, $35 \%$ of the complex is made up of fully dry areas, and approximately $50 \%$ is made up of aquatic-terrestrial transition areas, comprising permanently aquatic and permanently terrestrial habitats (lightly flooded or flooded for about 3 to 6 months) (Junk \& Wantzen, 1989).

It is composed of a mosaic of habitats, including the Cerrado, the Chaco, some components of the Caatinga, and ecosystems of the periamazonic region with a spatial habitat heterogeneity characteristic of this type of formation (Ab'saber, 1988; Guimarães, Trevelin \& Manoel, 2014). The Pantanal can be considered a large environmental transition zone and, like other ecotones, is characterized by high biodiversity and is among the most productive areas in the world (Calheiros \& Ferreira, 1997).

Given its environmental and cultural relevance and unique characteristics, it is recognized as a National Heritage Site by the Federal Constitution and considered a Biosphere Reserve and a World Heritage Site by UNESCO (United Nations Educational, Scientific and Cultural Organization). Also, the region is home to three sites recognized by the Convention on Wetlands of International Importance (Ramsar), namely the Private Reserve of the Fazenda Rio Negro Natural Heritage (RPPN/FRN, for its acronyms in Portuguese), the Pantanal Mato-Grossense National Park (PARNA, for its acronyms in Portuguese) and the Private Reserve of the SESC Pantanal Natural Heritage (RPPN/SESC, for its acronyms in Portuguese) (Fig. 1). 
Figure 1: Pantanal location map highlighting the region's three Ramsar sites: the Pantanal Mato-Grossense National Park (135.000 ha), the RPPN Fazenda Rio Negro (38.000 ha), and the RPPN SESC Pantanal (106.000 ha). Source: Mioto, Albrez \& Paranhos Filho (2012 (Pantanal Limits), ICMBio 2018a (Limit of Conservation Units), and MMA 2019 (Limit of Latin America and the Federative States).
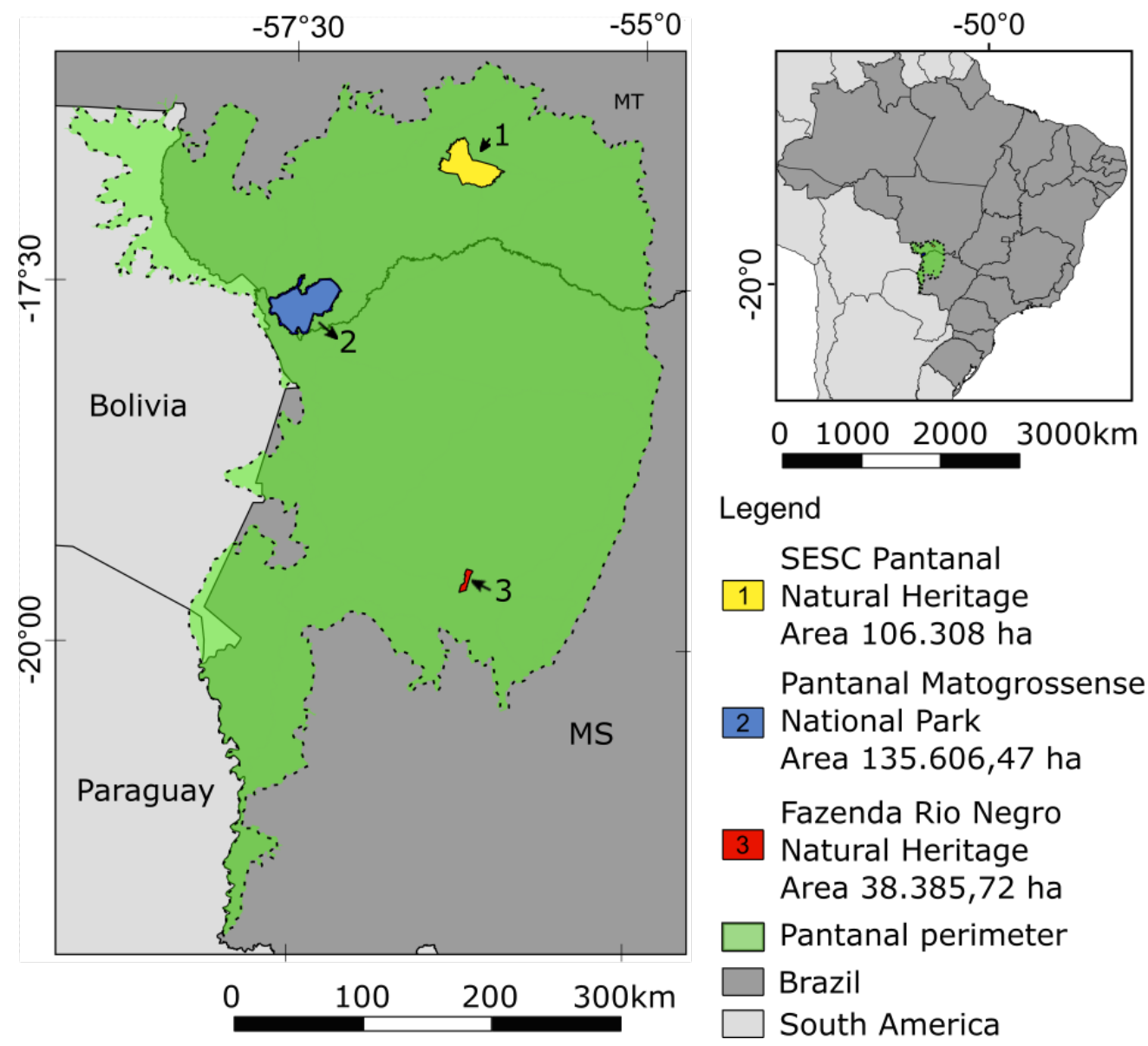

Located in the municipality of Barão de Melgaço (MT), RPPN/SESC is a privately owned nature reserve managed by the Social Service of Commerce (SESC, for its acronyms in Portuguese) who is responsible for delivering environmental education and low impact ecotourism activities, under the supervision of the Brazilian Institute of Environment and Renewable Natural Resources (IBAMA, for its acronyms in Portuguese) (Alho et al., 2011). Positioned in the so-called Poconé Pantanal, much of its territory is predominantly flooded during the rainy season (ICMBio, 2018b).

The PARNA is located in the Upper Pantanal, in the southwest of Mato Grosso, at the confluence of the Paraguay and Cuiabá rivers (ICMBio, 2003). As a protection mechanism, in addition to this Ramsar site, there are four conservation units considered as natural world heritage sites by UNESCO (2000), including the National Park under the management of the Chico Mendes Institute for Biodiversity Conservation (ICMBio, for its acronyms in Portuguese) and three RPPNs: Dorochê (northern border of the park, plain region, and predominance of Cerrado), Acurizal and Penha (to the south, located in the state of Mato Grosso do Sul, Serra do Amolar region). 
The RPPN/FRN is located in an area delimited by the Negro River from east to west, in the Abobral and Nhecolândia sub-regions. Its relief is slightly undulating and contributes to the formation of a diverse range of landscapes (ICMBio, 2018c). Another characteristic feature is the shallow lake basins that range from slightly acidic to highly alkaline, known as bays and salines, respectively (Machado, Silva, Pinto, Camargo \& Ribeiro, 2009).

Because these areas are Ramsar sites, it is easier to obtain support and access to international funds for project financing, in exchange for maintaining the ecological processes and conserving the local biodiversity. Due to their high potential to present a native vegetation cover, they were selected for the spectral analysis.

\section{Data Processing}

In this study, scenes obtained in 2017 and 2018 from the medium resolution satellites Landsat 8 'Earth Explorer 2018a,b,c,d,e,f', Sentinel-2 'Earth Explorer 2018g,h,e,i,k,l' and CBERS-4 'INPE 2018a,b,c,d,e,f', were used for analyses.

Six Landsat 8 Operational Land Imager (OLI) images with a $30 \mathrm{~m}$ spatial resolution referring to the orbits/points 227/72, 226/72, and 226/74, twelve CBERS-4 images, six with the MUX sensor (multispectral camera), and six with the IRS sensor (multispectral and thermal imaging), with spatial resolutions of $20 \mathrm{~m}$ and $40 \mathrm{~m}$, respectively, referring to orbits/points 165/122, 165/119 and 167/120; and six Sentinel-2 images, with an MSI (Multispectral Instrument) sensor, with spatial resolutions of $10 \mathrm{~m}$ and $20 \mathrm{~m}$, referring to orbits/points 21KWU, 21KVA, and 21KWB were used.

According to the geographical position of each analyzed site, the dry and rainy seasons were identified, and one scene from each season was selected per satellite from those with the highest image quality and the lowest cloud coverage (Table 1). Initially, scenes from the same year (2017 or 2018) were selected; however, it was not possible to obtain CBERS-4 and Sentinel 2 scenes with the above characteristics in the same year and, therefore, images from both years were selected here.

Table 1: Data from the scenes used in this study being one scene from each season of each analyzed site per satellite.

\begin{tabular}{l|l|l|l|l}
\hline SATELITE & ORBIT / OINT & SENSOR & RAINY & DRY \\
\hline \multirow{4}{*}{ LANDSAT 8} & $227 / 72$ & OLI & $29 / 04 / 2017$ & $16 / 09 / 2017$ \\
\cline { 2 - 5 } & $226 / 72$ & OLI & $01 / 02 / 2017$ & $13 / 09 / 2017$ \\
\cline { 2 - 5 } & $226 / 74$ & OLI & $21 / 03 / 2017$ & $28 / 08 / 2017$ \\
\hline \multirow{5}{*}{ CBERS-4 } & $165 / 122$ & MUX & $15 / 04 / 2017$ & $23 / 08 / 2017$ \\
\cline { 2 - 5 } & $165 / 122$ & IRS & $15 / 04 / 2017$ & $23 / 08 / 2017$ \\
\cline { 2 - 5 } & $166 / 119$ & MUX & $08 / 05 / 2017$ & $15 / 09 / 2017$ \\
\cline { 2 - 5 } & $166 / 119$ & IRS & $08 / 05 / 2017$ & $15 / 09 / 2017$ \\
\cline { 2 - 5 } SENTINEL-2 & $167 / 120$ & MUX & $08 / 04 / 2018$ & $12 / 09 / 2017$ \\
\cline { 2 - 5 } & $167 / 120$ & IRS & $08 / 04 / 2018$ & $12 / 09 / 2017$ \\
\hline & $21 K V A$ & MSI & $27 / 04 / 2018$ & $26 / 07 / 2017$ \\
\hline & $21 K W U$ & MSI & $22 / 04 / 2018$ & $10 / 08 / 2018$ \\
\hline & $21 K W B$ & MSI & $07 / 01 / 2017$ & $04 / 09 / 2017$ \\
\hline
\end{tabular}


The QGIS 2.18 (QGIS Development Team, 2017) software, licensed under the General Public License (GNU), was used for all operations.

Once the images were gathered, the imaged bands of the three satellites were compared in order to define the corresponding bands to be used for each sensor to create the false-color composite images (Fig. 2).

The IRS sensor bands (CBERS-4) were resampled from $40 \mathrm{~m}$ to $20 \mathrm{~m}$ to be stacked with the MUX bands (CBERS-4). The MSI (Sentinel-2) sensor bands were converted to GeoTIFF format for uniformity, and the $20 \mathrm{~m}$ bands resampled to $10 \mathrm{~m}$ and then stacked. The Landsat 8 images did not require resampling or GeoTIFF conversion, only stacking.

Subsequently, all stacks were redesigned for the Universal Transverse Mercator (UTM), Zone 21 South, and Datum SIRGAS 2000 projection. The images were then cut using the clip tool, remove all but the analyzed regions. To this end, we used the shapefiles available on the ICMBio website (2018).

Figure 2: Comparative analysis of Landsat 8, CBERS-4, and Sentinel-2 imaged bands. Bands 10 and 11 of IRS (CBERS-4), and 11, and 12 of MSI (Sentinel-2) were resampled (shaded boxes). Source: USGS (2018), INPE (2018), and ESA (2018).

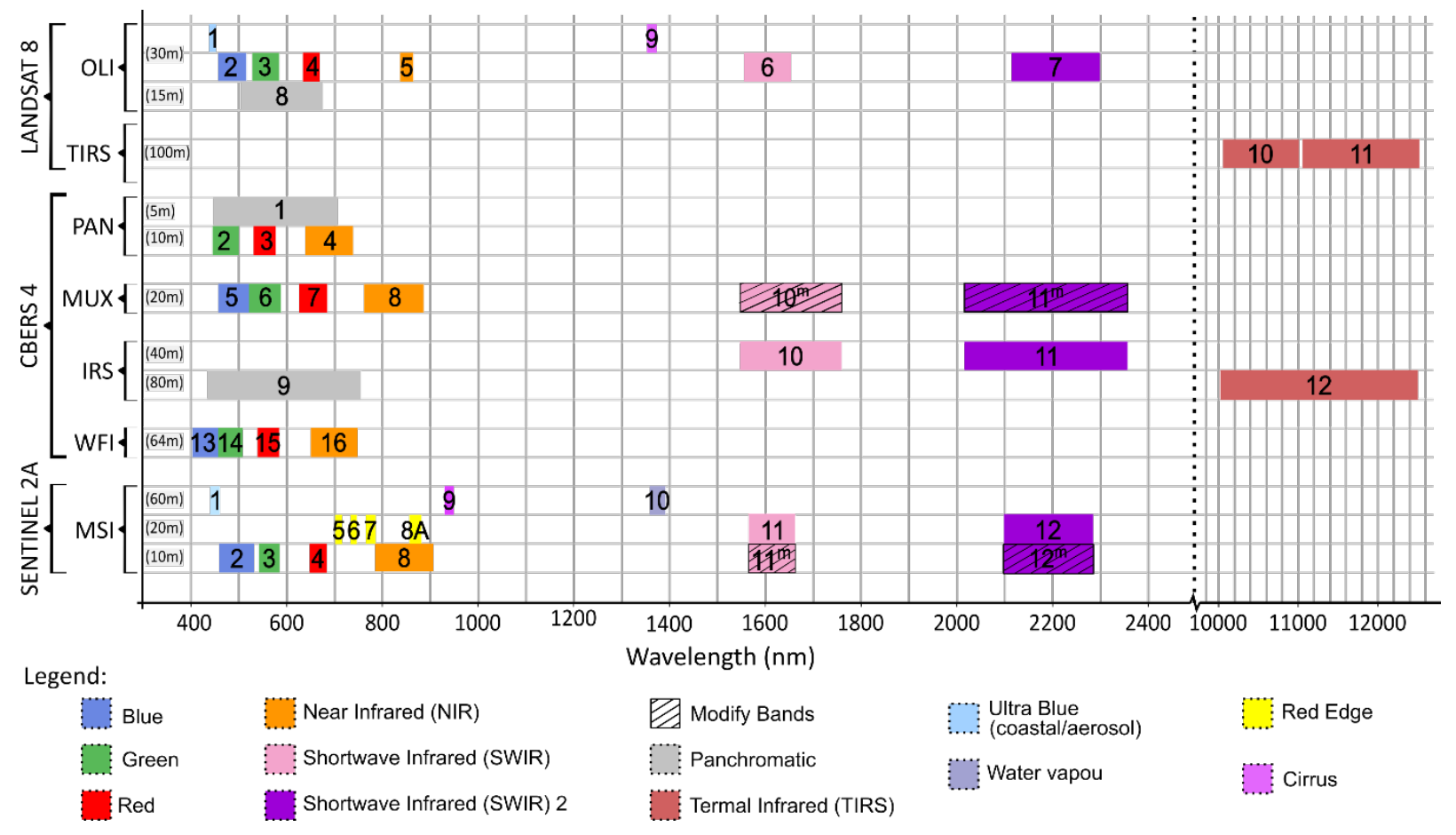

Three different combinations of three spectral bands for false-color composite image generation and their corresponding bands for each sensor were selected for photointerpretive analysis of the Pantanal sub-regions as follows:

- Near-Infrared (NIR), Shortwave Infrared (SWIR), and red corresponding to the 5 - 6 - 4 bands in Landsat 8 (OLI sensor); 8 - 10 - 7 in CBERS-4 ${ }^{\mathrm{M}}$ (MUX and IRS sensors), and 8 - 11 - 4 in Sentinel-2 ${ }^{\mathrm{M}}$ (MSI sensor), respectively; 
- Red, NIR, and green corresponding to the 4 - 5 - 3 bands in Landsat 8 (OLI), 7 - 8 6 in CBERS- $4^{\mathrm{M}}$ (MUX) and 4 - 8 - 3 in Sentinel-2 ${ }^{\mathrm{M}}$ (MSI), respectively;

- Shortwave Infrared 2 (SWIR 2), NIR, and blue corresponding to the 7 - 5 - 2 bands in Landsat 8 (OLI), 11 - 8 - 5 in CBERS-4 ${ }^{\mathrm{M}}$ (MUX and IRS sensors) and 12 - 8 - 2 in Sentinel-2 ${ }^{\mathrm{M}}(\mathrm{MSI})$, respectively.

The images were subsequently enhanced to achieve better visualization with the naked eye, aiding to identification of ground cover patterns. To improve our understanding of the nature of the dynamic Pantanal ecosystem, permanently dry and permanently flooded areas were analyzed. The classes used in the ground cover identification were: dry area with undergrowth; dry area with tree-shrub vegetation; humid undergrowth area; flood area with tree-shrub vegetation; wetland; free water surface; sediment-water; water. The Morro Caracará (MT), in the Pantanal Mato-Grossense National Park, was considered the most significant among the sites. After analyzing all images from both the dry and rainy seasons from all three study sites, it was decided that only the Pantanal Mato-Grossense National Park will be discussed here.

The three studied sites show a high degree of correlation among the types of vegetation present; however, the Morro do Caracará site has a greater potential of having a native vegetation cover. As stated by the National System of Conservation Units (SNUC), the objective of this National Park is the preservation of natural ecosystems of great ecological relevance and scenic beauty.

According to the management plan, the Morro do Caracará is characterized by pediplains of varying sizes surrounded by flooded forests. In the rainy season, the humid soil has a thick layer of peat. Seasonal deciduous forest covers much of the Morro do Caracará, but some areas are forest-savannah transition or semi-deciduous seasonal forest biomes. It presents 'differences in the herbaceous species cover between seasons; this being smaller during the drought and with more presence of peat, resulting from the leaf fall of the trees. (ICMBio, 2003, p. 70). On gradients with slopes of 30\% and 45\%, the herbaceous vegetation is predominant, identified as rupestrian field vegetation. Interspersed with this herbaceous vegetation, unsteady shrubs and cacti occur.

\section{RESULTS}

\section{Correlation between satellites}

The first false-color composite image used the NIR-SWIR-RED bands (5-6-4 in Landsat 8, 8-10-7 in CBERS-4 ${ }^{\mathrm{M}}$, and 8-11-4 in Sentinel-2 ${ }^{\mathrm{M}}$ ) (Figs. 3, 4, and 5). With high reflectance in the NIR band, the photosynthetically active tree-shrub vegetation corresponds to a reddish color. In the CBERS- $4^{\mathrm{M}}$ scenes, the contrast between these vegetation areas and other areas is greater, and thus presents a more vibrant coloration. Wetlands or flooded areas, with or without the presence of sediment or macrophytes, are indicated by a navyblue to black color in all sensors. This response occurs because the visible band (red), 
which presents high water reflectance, is assigned to the blue channel. Dry areas with undergrowth correspond to water-green tones.

In the composite image of the PARNA (Fig. 3), areas with humid tree-shrub vegetation (orange) were identified. In the eastern portion of the park this vegetation is intertwined with large lagoons (blue), and in the western portion with wetlands (shades of dark blue).

In the RPPN/FRN, the presence of lagoons (blue coloration) in the western portion of the site is highlighted, which during the drought present areas of undergrowth in its surroundings (Fig. 4).

The RPPN/SESC scenes (Fig. 5) feature more areas with undergrowth without a free water surface (water-green). During the dry season, the tree-shrub vegetation in the eastern portion of the region also has a reddish tone, indicating that it is photosynthetically active. During the rainy period, these regions moisten and turn orange. Few wetlands are found, appearing mainly during the floods in the northeast region.

Figure 3: False-color composite images of the Pantanal Mato-Grossense National Park for the scenes of the three satellites using a NIR-SWIR-RED band combination.




Figure 4: False-color composite images of the SESC Pantanal Natural Heritage for the scenes of the three satellites using a NIR-SWIR-RED band combination.
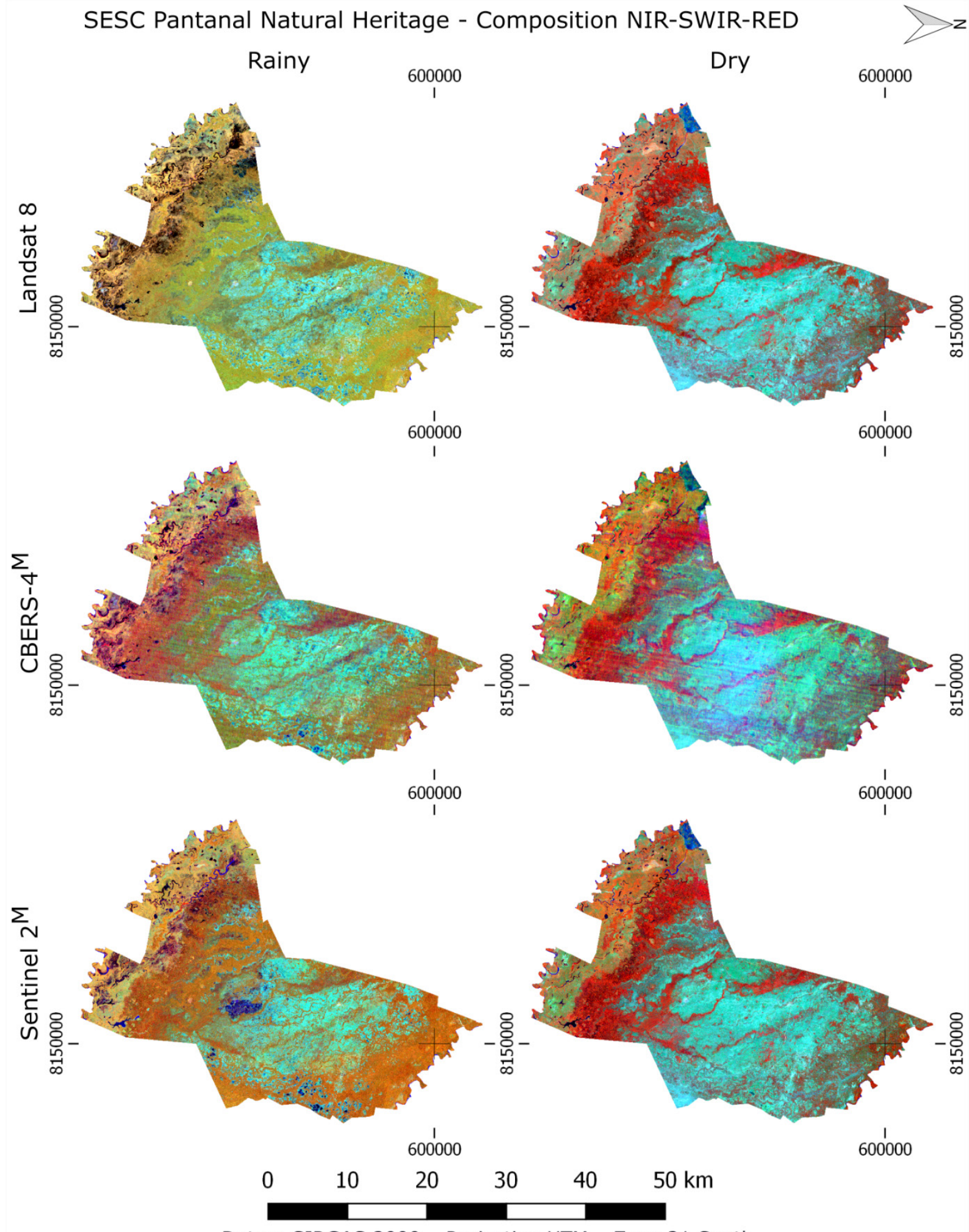

Datum SIRGAS 2000 _ Projection UTM _ Zone 21 South

Data Base: Landsat 8 OLI Orbit/Point 226/72 Acquisition Date: 1/Feb/2017 (Rainy) 11/Set/2017 (Dry)

CBERS-4 MUX and IRS Orbit/Point 166/119 Acquisition Date: 8/May/2017 (Rainy) 15/Set/2017 (Rainy) Sentinel 2 MSI Orbit/point 21KWB Acquisition Date: 7/Jan/2017 (Rainy) 4/Set/2017 (Dry) 
Figure 5: False-color composite images of the Fazenda Rio Negro Natural Heritage for the scenes of the three satellites using a NIR-SWIR-RED band combination.
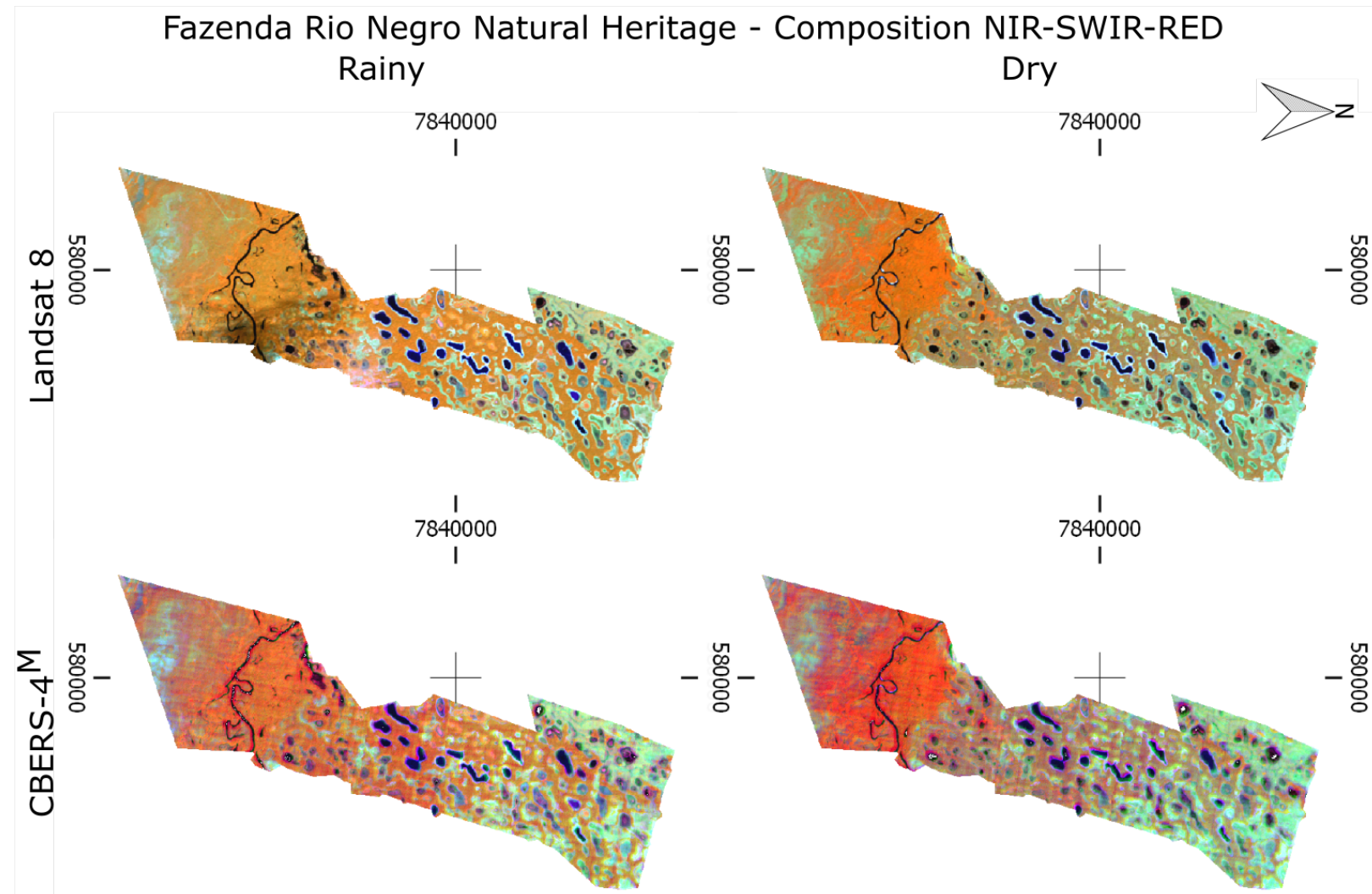

I
7840000
I
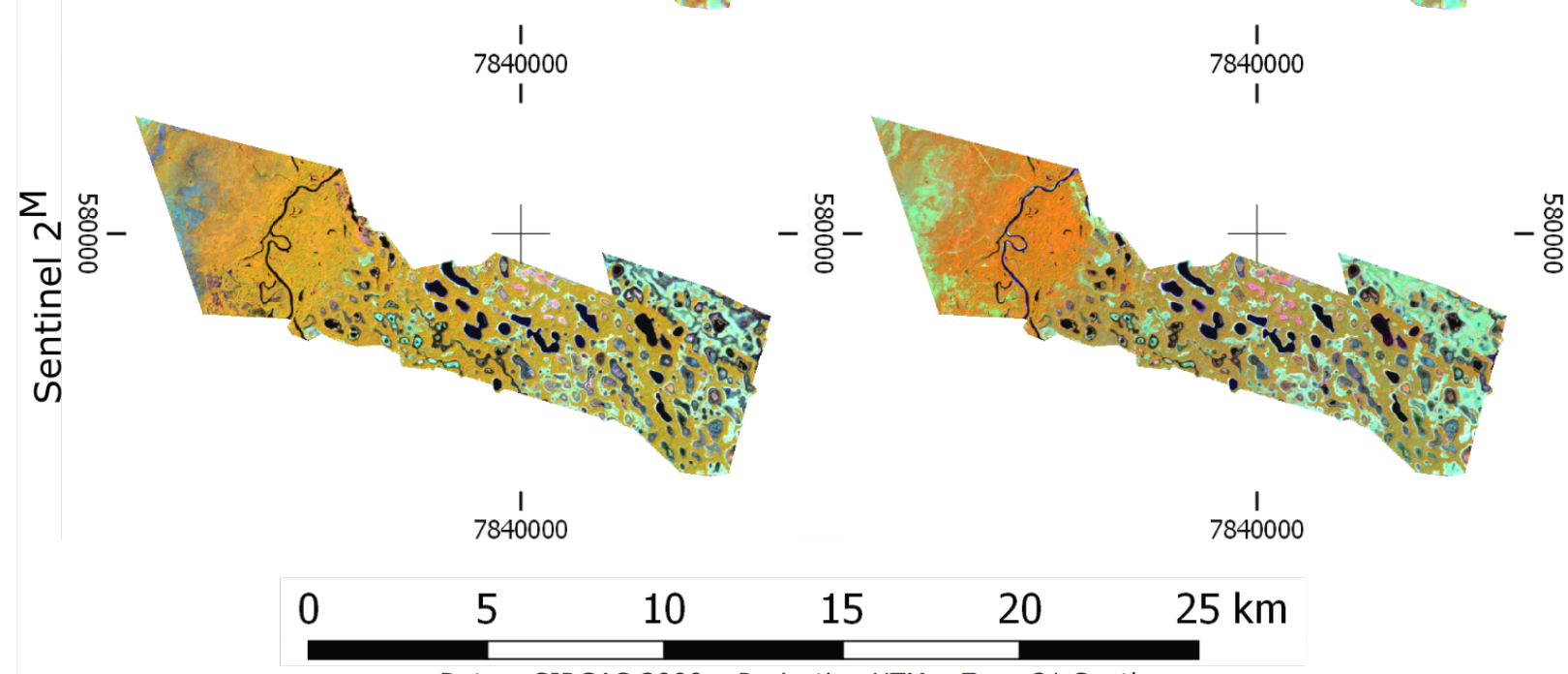

Datum SIRGAS 2000 _ Projection UTM _ Zone 21 South

Data base: Landsat 8 OLI Orbit/Point 226/74 Acquisition Date: 21/Mar/2017 (Rainy) 28/Aug/2017 (Dry) CBERS-4 MUX and IRS Orbit/Point 165/122 Acquisition Date: 15/Apr/2017 (Rainy) 12/Aug/2017 (Dry) Sentinel 2 MSI Orbit/point 21KWU Acquisition Date: 22/Apr/2018 (Rainy) 10/Aug/2018 (Dry) 
The second spectral band combination, RED-NIR-GREEN (4-5-3 in Landsat 8, 7-86 in CBERS- ${ }^{\mathrm{M}}$, and 4-8-3 in Sentinel-2 ${ }^{\mathrm{M}}$ ), produced false-color composite images with predominantly pink and green coloration (Figs. 6, 7, and 8). Associated with flooded areas, shades of pink to lilac are visual responses of the largest water reflections in the visible region (red and green), assigned to the red and blue channels of the multispectral image. The darker shades of the same colors indicate areas with cleaner waters.

Figure 6: False-color composite images of the Pantanal Mato-Grossense National Park for the scenes of the three satellites using a RED-NIR-GREEN band combination.

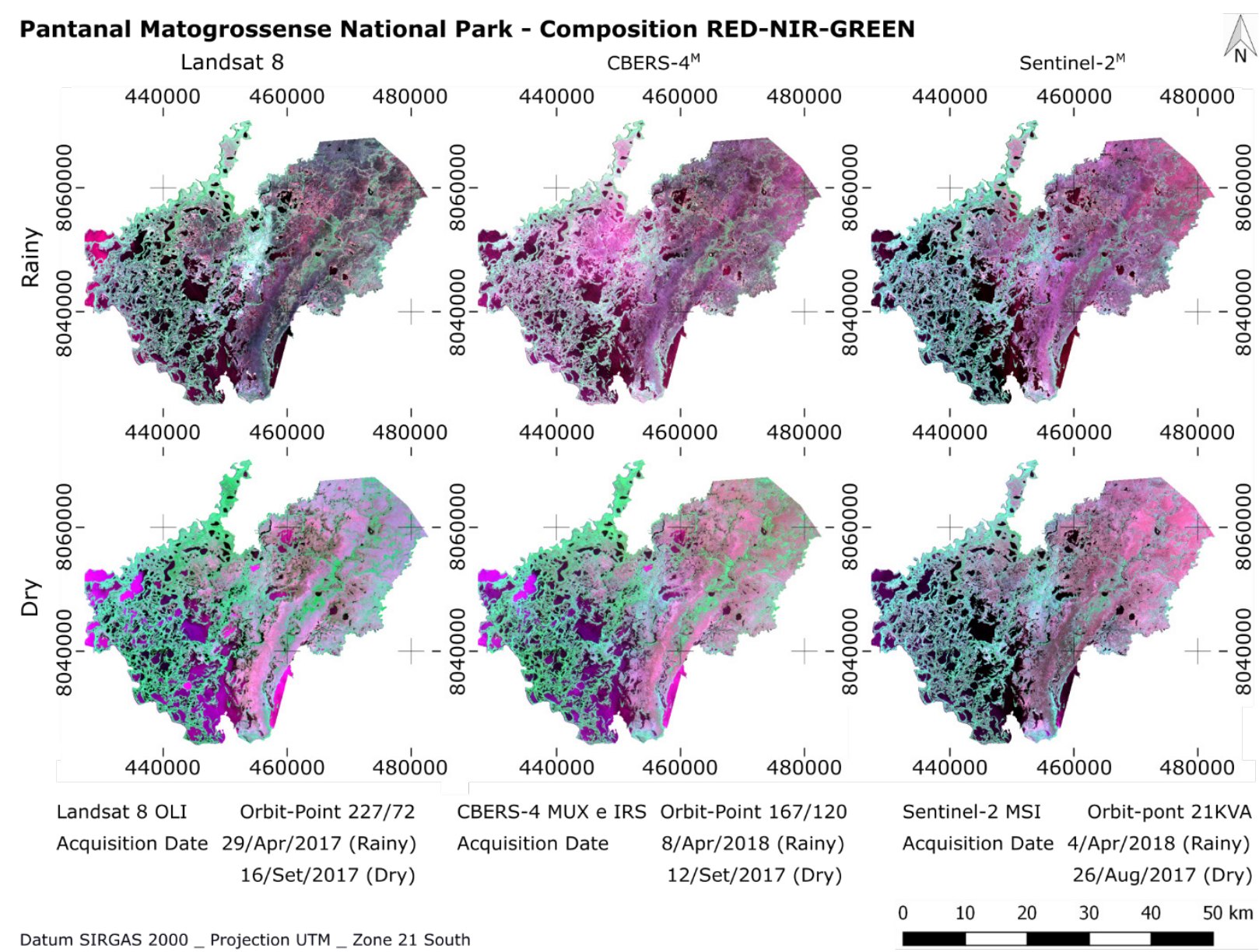


Figure 7: False-color composite images of the Fazenda Rio Negro Natural Heritage for the scenes of the three satellites using a RED-NIR-GREEN band combination.

\section{Fazenda Rio Negro Natural Heritage - Composition RED-NIR-GREEN \\ Rainy \\ Dry}
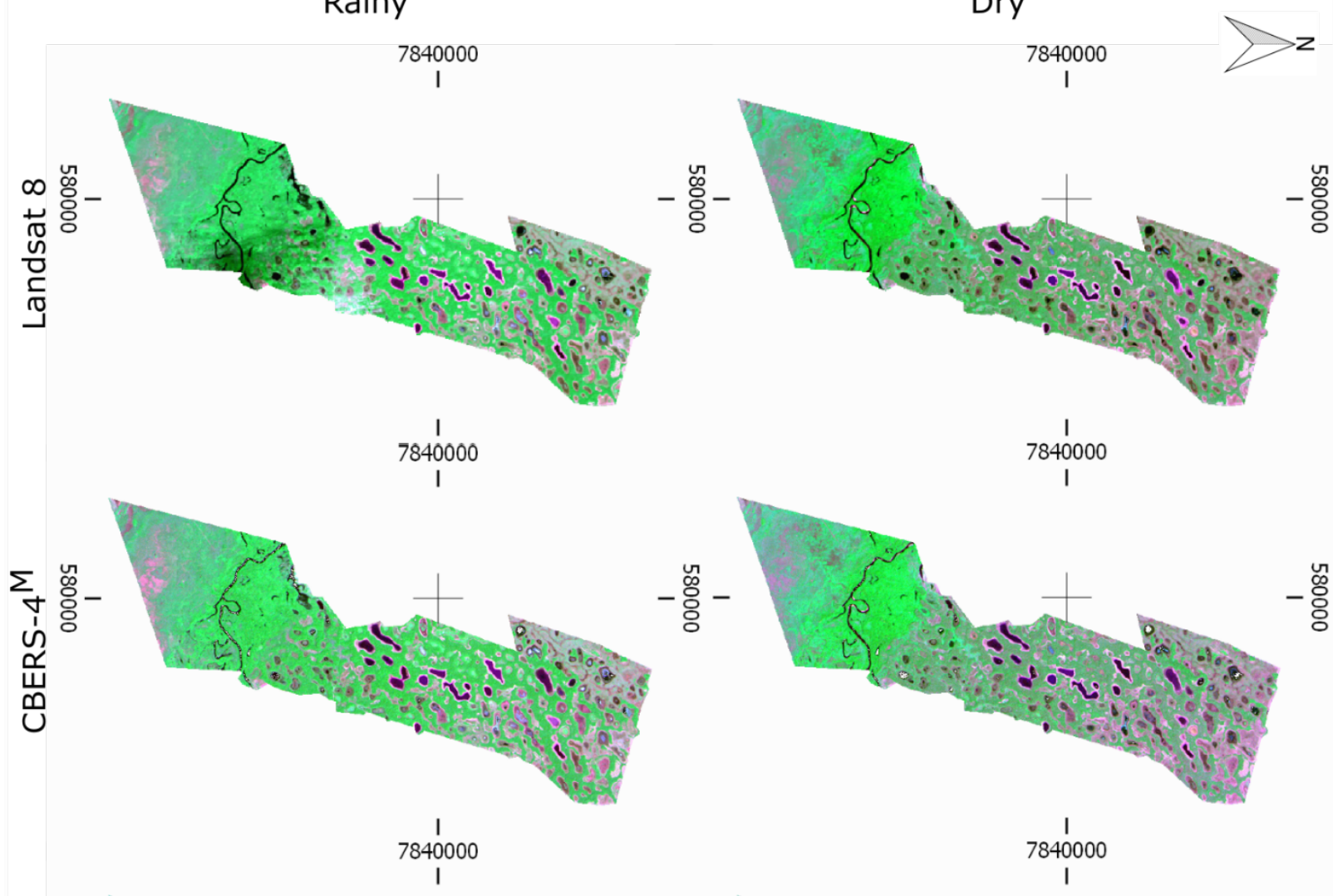

$\frac{1}{7840000}$

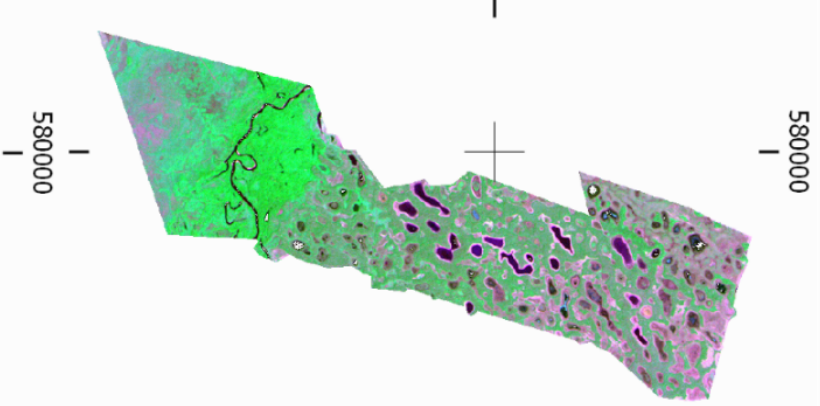

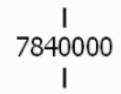
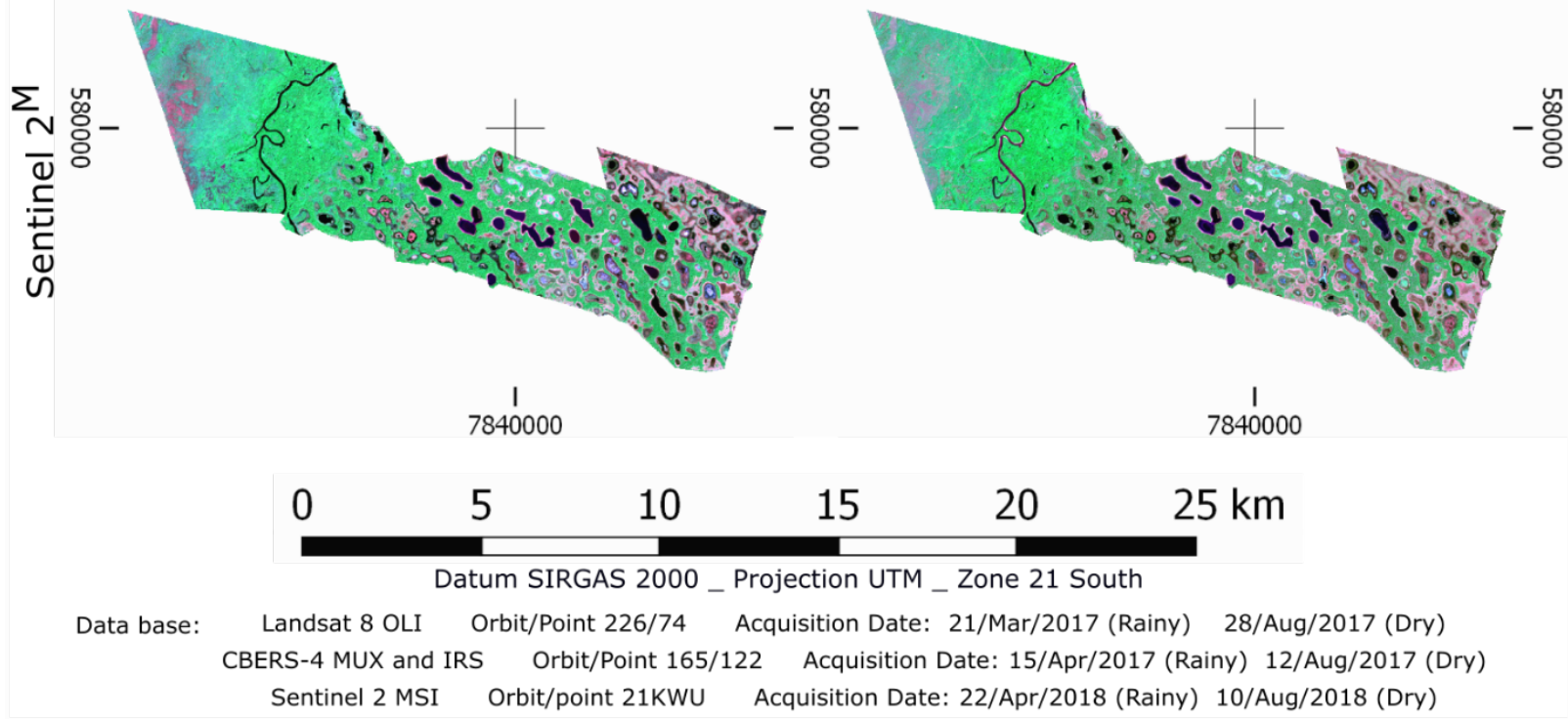

In this type of false-color composite image, the wetlands are confused with the flooded, clean water areas in the Landsat 8 and CBERS- $4^{\mathrm{M}}$ scenes, while in the Sentinel$2^{\mathrm{M}}$ scenes cleaner water surfaces correspond to black, facilitating their identification from other areas.

In the RPPN SESC composition, wetlands are confused with areas of undergrowth. 
Figure 8: False-color composite images of the SESC Pantanal Natural Heritage for the scenes of the three satellites using a RED-NIR-GREEN band combination.
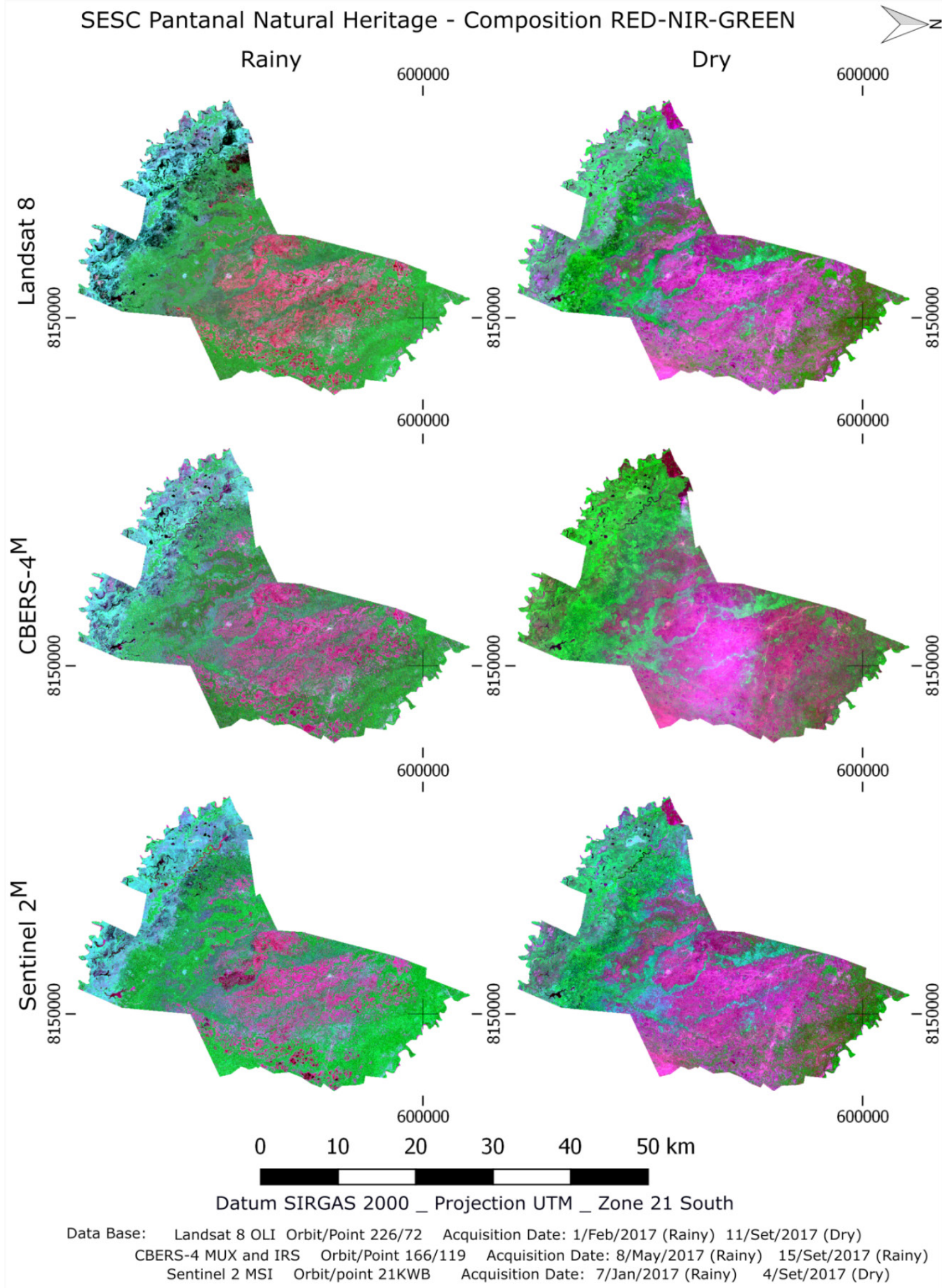
The last false-color composite image, using a combination of SWIR 2-NIR-BLUE spectral bands (7-5-2 in Landsat 8, 11-8-5 in CBERS- $4^{\mathrm{M}}$, and 12-8-2 in Sentinel-2 ${ }^{\mathrm{M}}$ ), presents more differentiated coloration between the three satellites (Figures 9, 10, and 11). The flooded areas in the Landsat 8 scenes are brown, while they correspond to a navy-blue tone in the CBERS- $4^{\mathrm{M}}$ scenes, and purple in the Sentinel- $2^{\mathrm{M}}$ scenes. This response occurs due to differences in the imaged range of each sensor.

Since the spectral response of water is more intense in the visible range, while that of the exposed soils is more intense in the SWIR 2 range, the false-color composite images with these ranges resulted in equally higher reflectance values in the red and blue channels, respectively. The differences in the spectral ranges imaged by the sensors, especially for the SWIR 2 band, cause these slightly distinct visual responses from purple to brown. Due to the reflectance of the target in the NIR region, and since they correspond to the green channel of the composite image, the areas with vegetation show shades of green.

Figure 9: False-color composite images of the Pantanal Mato-Grossense National Park for the scenes of the three satellites using a SWIR 2-NIR-BLUE band combination.

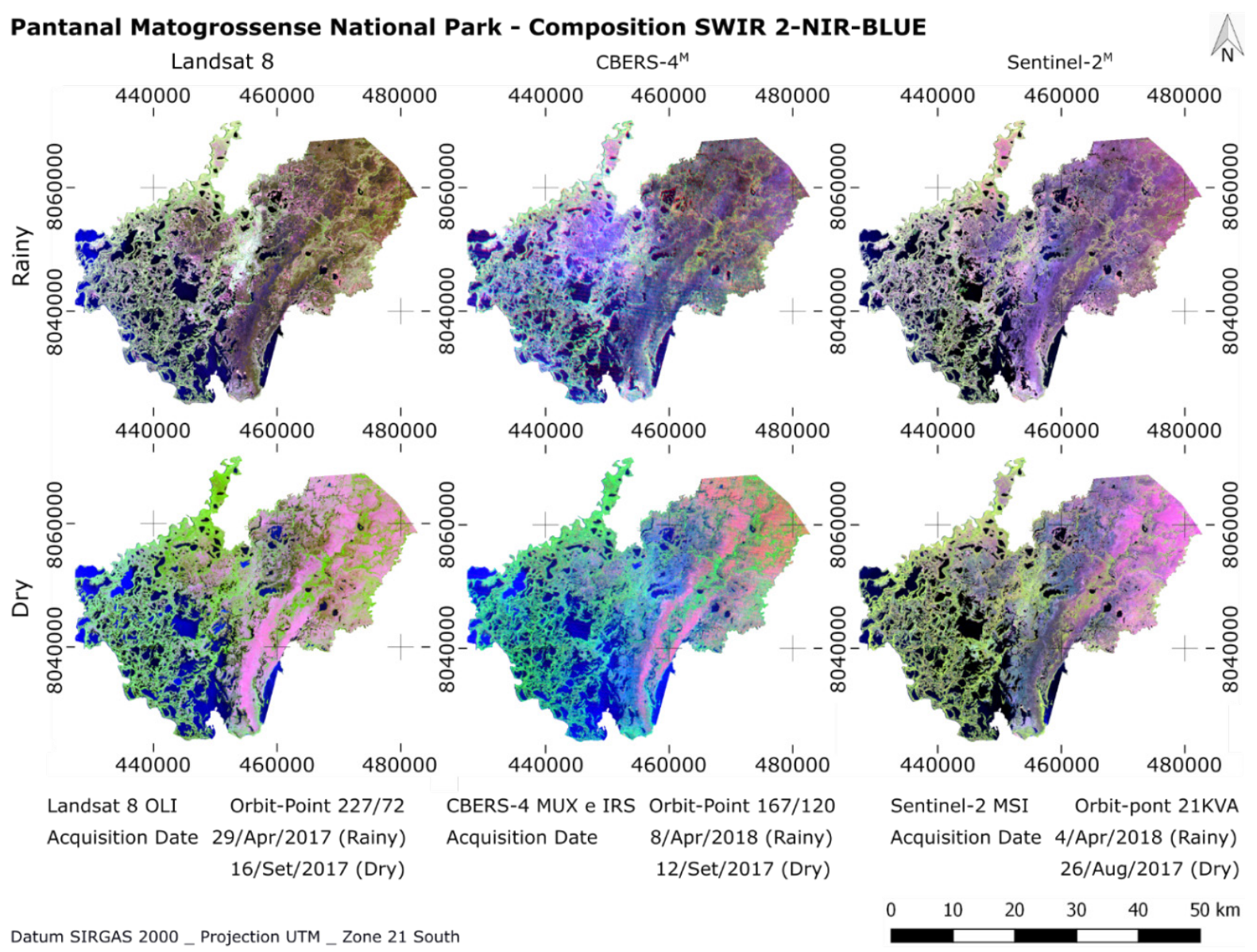


Figure 10: False-color composite images of the Fazenda Rio Negro Natural Heritage for the scenes of the three satellites using a SWIR 2-NIR-BLUE band combination.

\section{Fazenda Rio Negro Natural Heritage - Composition SWIR 2-NIR-BLUE Rainy}
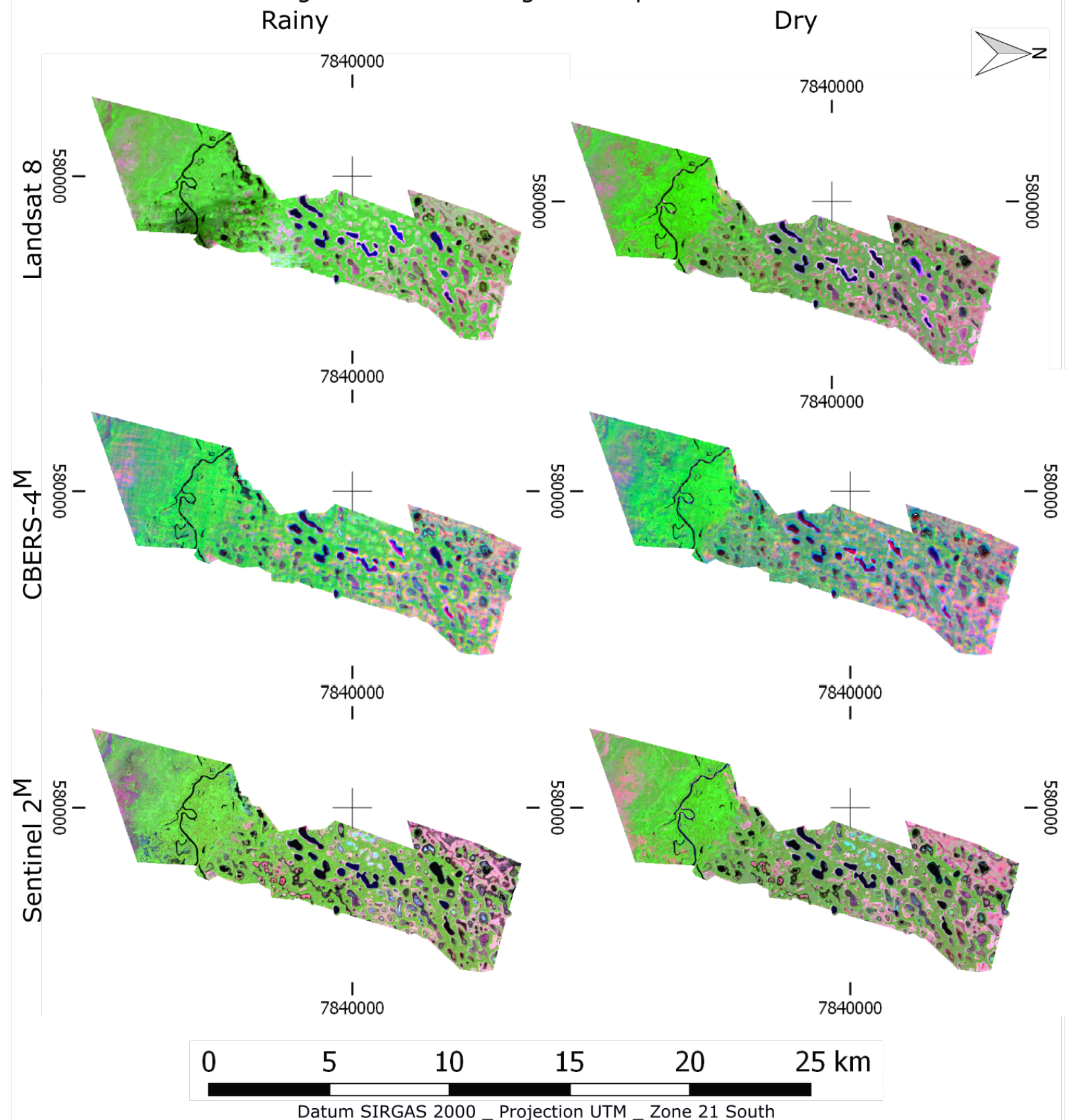

Data base: Landsat 8 OLI Orbit/Point 226/74 Acquisition Date: 21/Mar/2017 (Rainy) 28/Aug/2017 (Dry) CBERS-4 MUX and IRS Orbit/Point 165/122 Acquisition Date: 15/Apr/2017 (Rainy) 12/Aug/2017 (Dry) Sentinel 2 MSI Orbit/point 21KWU Acquisition Date: 22/Apr/2018 (Rainy) 10/Aug/2018 (Dry) 
Figure 11: False-color composite images of the SESC Pantanal Natural Heritage for the scenes of the three satellites using a SWIR 2-NIR-BLUE band combination.
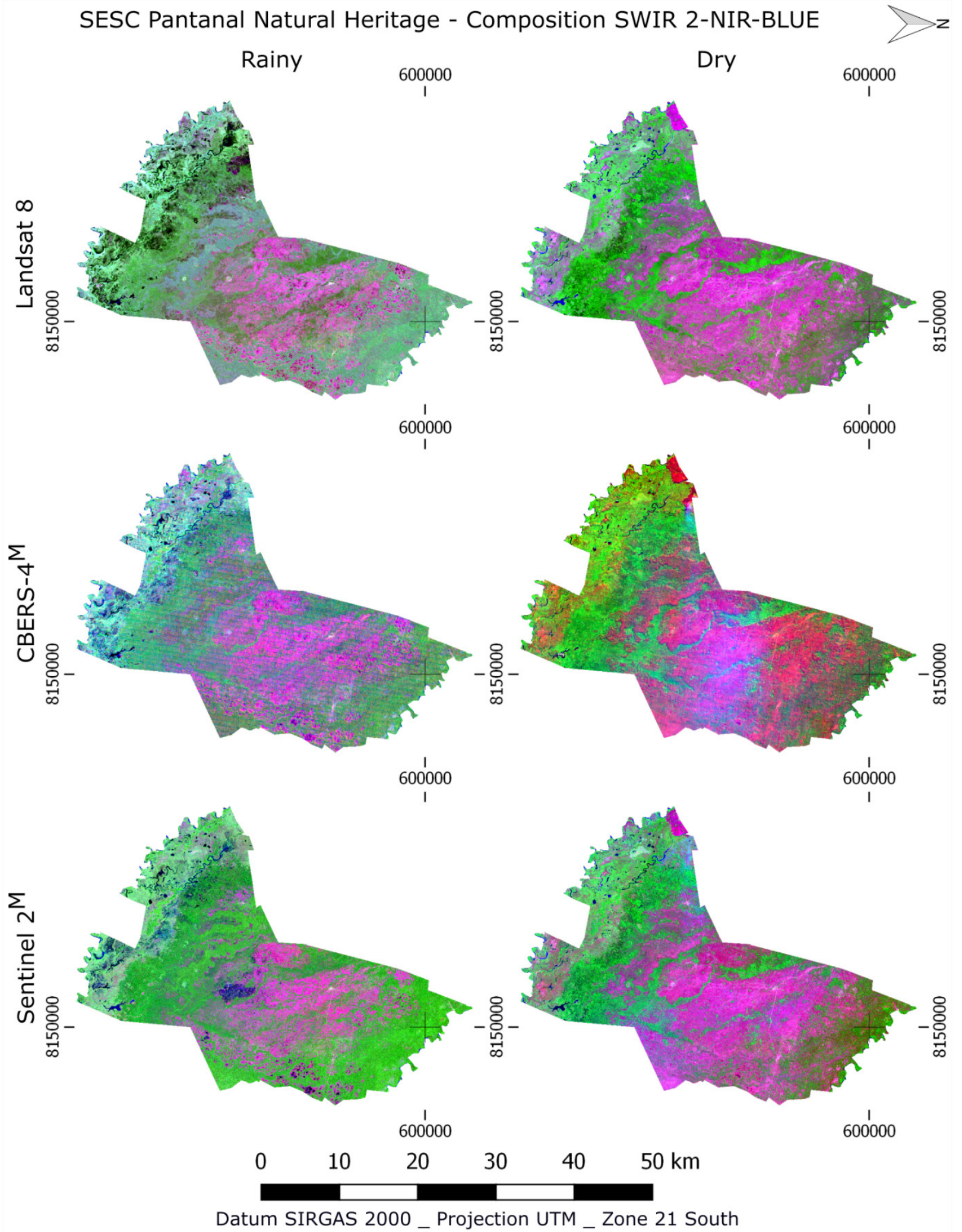

Data Base: Landsat 8 OLI Orbit/Point 226/72 Acquisition Date: 1/Feb/2017 (Rainy) 11/Set/2017 (Dry)

CBERS-4 MUX and IRS Orbit/Point 166/119 Acquisition Date: 8/May/2017 (Rainy) 15/Set/2017 (Rainy) Sentinel 2 MSI Orbit/point 21KWB Acquisition Date: 7/Jan/2017 (Rainy) 4/Set/2017 (Dry) 


\section{Correlation between the different false-color composite images of the same satellite}

To facilitate the interpretation of the different results, the composite images were separated by the sensor, and the specific color gradient legends were compiled for each image, allowing detailed evaluation of the ground cover identification and the specific behavior of each sensor.

At the top of Morro Caracará of PARNA, the vegetation is undergrowth (without free water surfaces), on the slope tree-shrubs. In the Landsat 8 NIR-SWIR-RED false-color composite image, the water-green tone corresponds to the areas of dry undergrowth, while the yellow to orange areas correspond to tree-shrub vegetation with higher photosynthetic activity. The black and navy-blue areas correspond to clean water (Fig. 12).

Figure 12: False-color composite images of the Landsat 8 scenes of the Pantanal Mato-Grossense National Park in the Morro Caracará area.

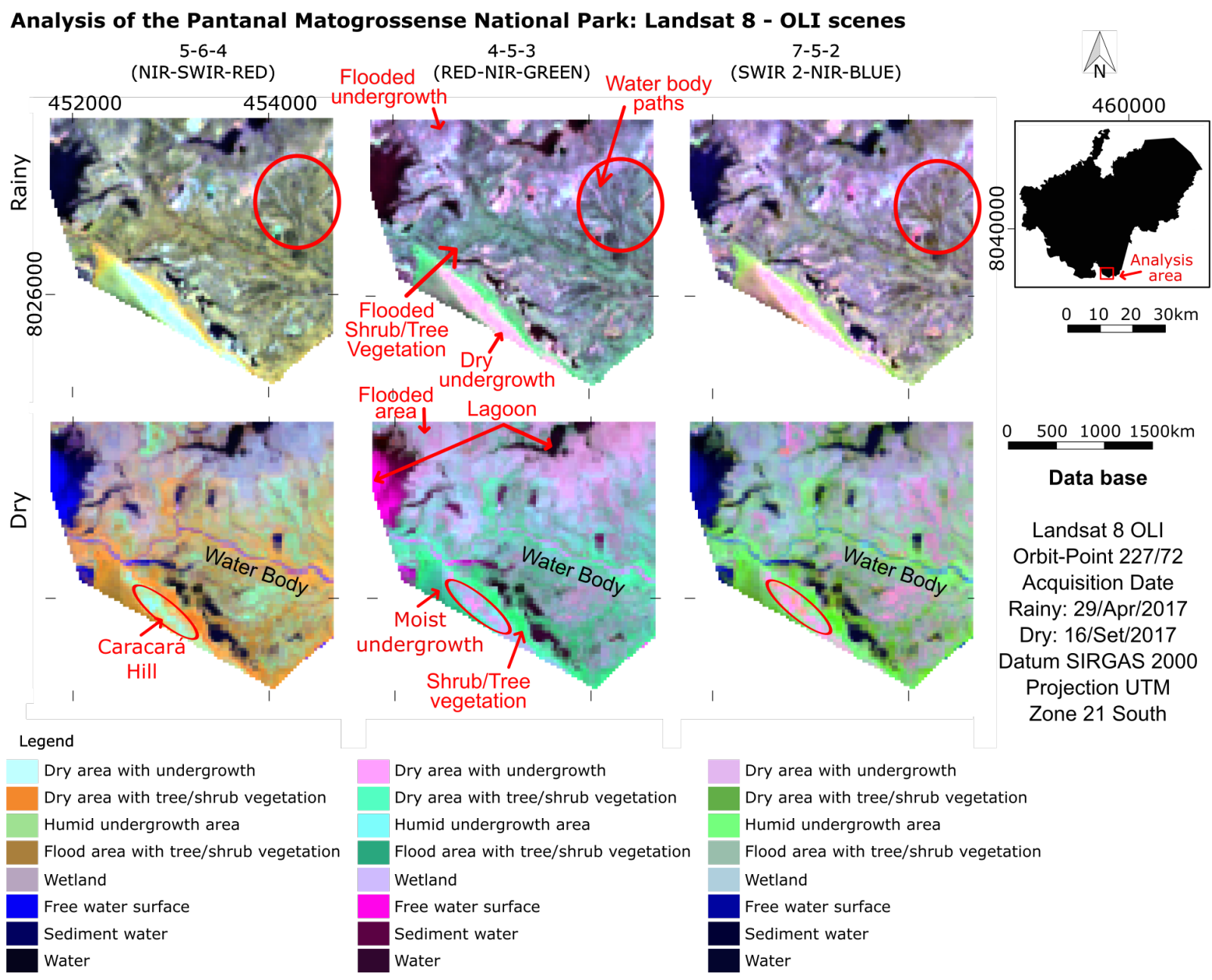

In the RED-NIR-GREEN false-color composite image, the difference in the color of the areas of undergrowth and areas with free water surfaces is very subtle, corresponding to light pink and pink tones, respectively. In the NIR-SWIR-RED and the SWIR 2-NIR-BLUE false-color composite images, the contrast between the two areas is clear, corresponding to the color scheme displayed in the gradation legend. 
In the SWIR 2-NIR-BLUE false-color composite image, the paths of the water bodies are evident and, as in the NIR-SWIR-RED composite image each component has a different color. However, the wetlands and the flood areas with tree-shrub vegetation are easy to recognize around the lagoon in the SWIR 2-NIR-BLUE image (opaque moss green) but only subtly different in the NIR-SWIR-RED (brown) and RED-NIR-GREEN (dark green) images, creating in the latter two an illusion of a flooded area with undergrowth in the northeastern portion of the analyzed area.

The CBERS- $4^{\mathrm{M}}$ images show prevalent cloud coverage throughout the analyzed period, resulting in false-color composite images that are difficult to interpret (Fig. 13).

Figure 13: False-color composite images of the CBERS-4 ${ }^{\mathrm{M}}$ scenes from the Pantanal Mato-Grossense National Park in the Monte Caracará area.

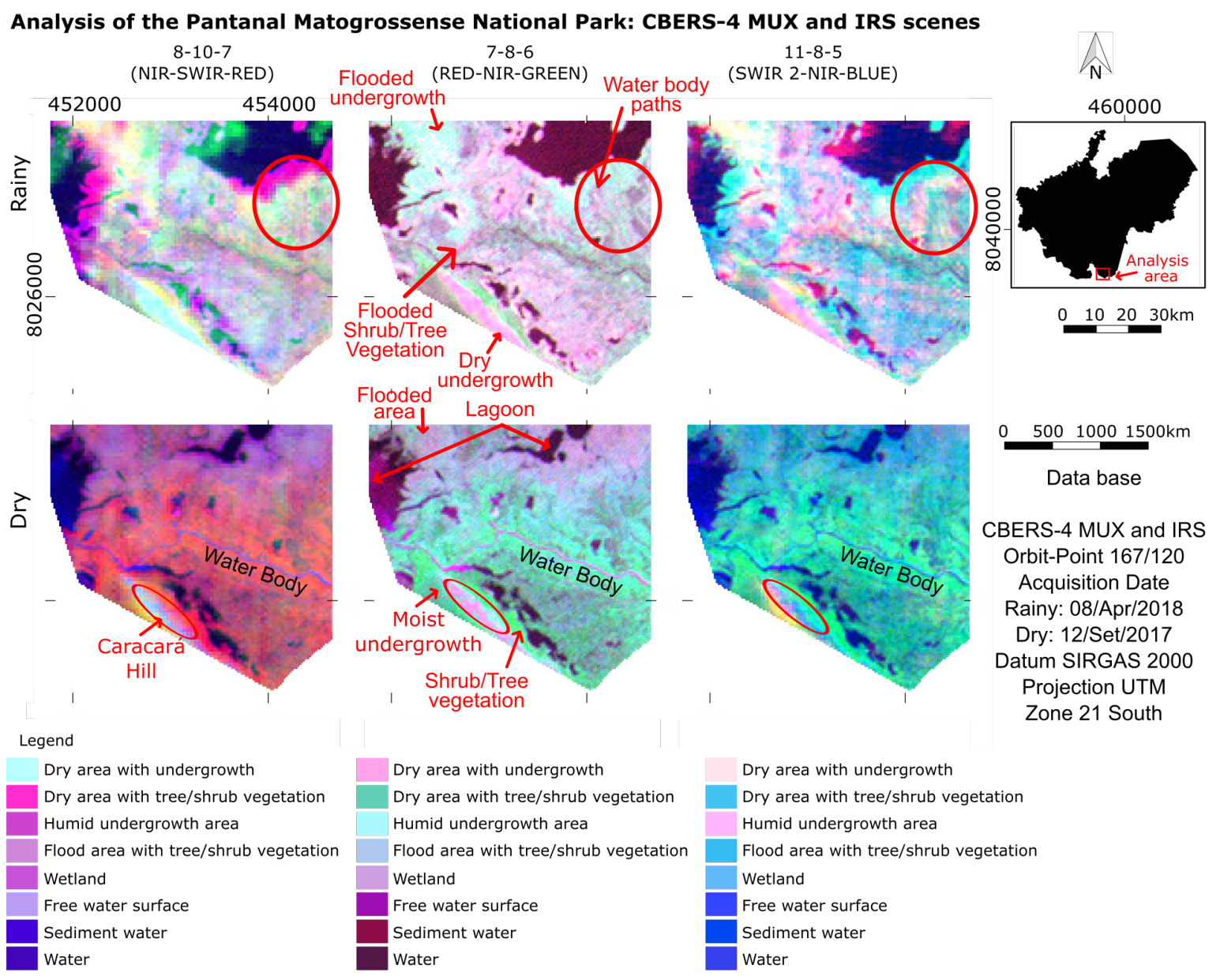

The combination of the MUX sensor (with the blue, green, red, and NIR bands) and the IRS sensors (SWIR and SWIR 2) was not realizable without geometric correction, resulting in spatially distorted images, that made comprehension difficult, and a gradation legend with very little contrast. The RED-NIR-GREEN false-color composite image, a product of bands from the MUX sensor only, gave a slightly clearer image of the terrain.

In the RED-NIR-GREEN false-color composite image, the dry undergrowth at the top of Morro Caracará corresponds to a light pink color, similar to that in the Landsat 8 
images (Figure 12), resulting in a very similar color scheme for the wetlands and the flood areas. Areas with dry tree-shrub vegetation (green), however, became evident, presenting a different color from the other areas.

In general, the Sentinel-2false-color composite images exhibit similar trends to those of the Landsat 8 images, with high contrast for dry areas in the NIR-SWIR-RED and SWIR 2-NIR-BLUE composite images compared to wetlands and flood areas (Fig. 14).

Figure 14: False-color composite images of Sentinel-2 scenes from the Pantanal Mato-Grossense National Park in the Monte Caracará area.

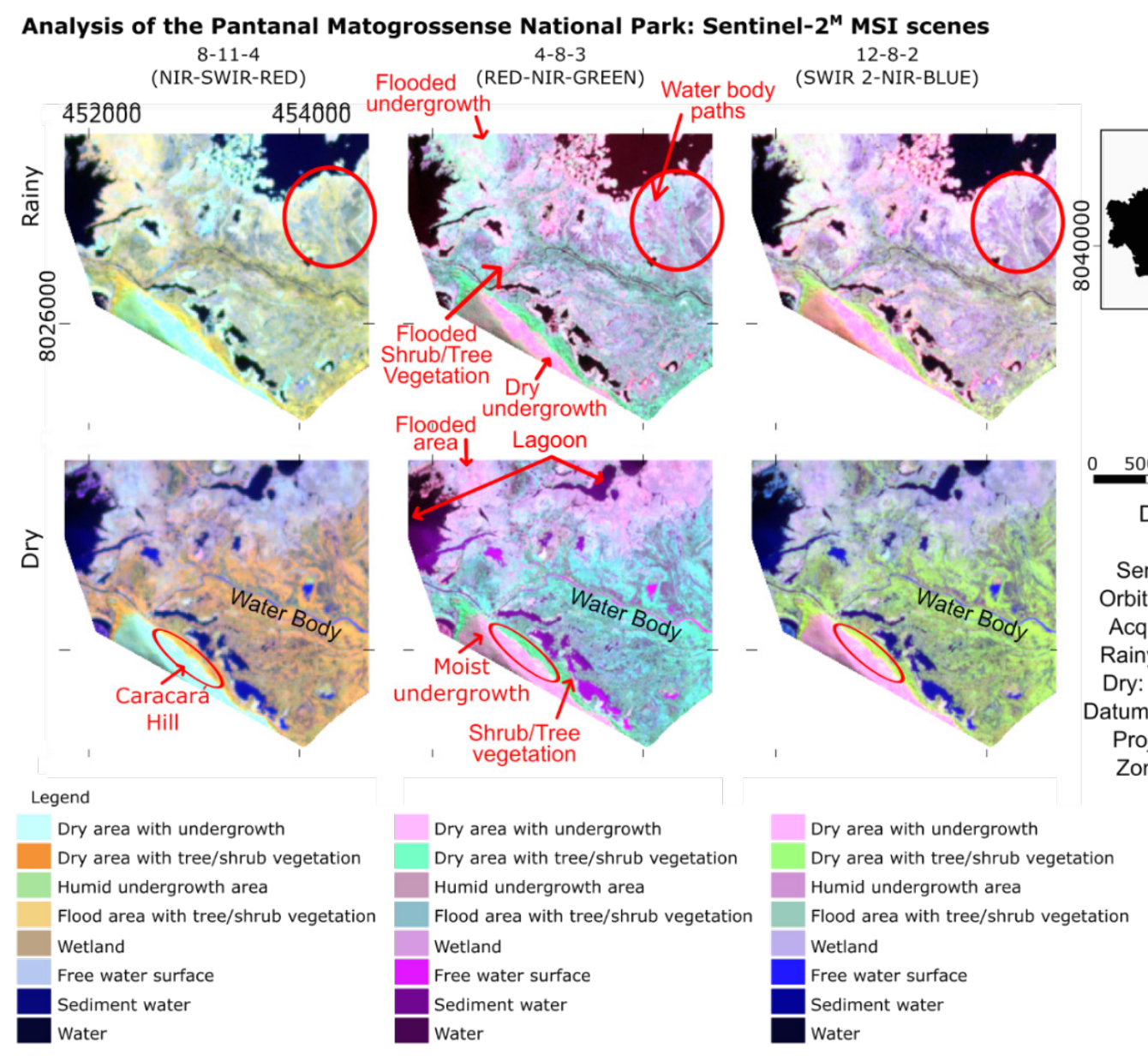

The difference between dry and flooded areas in the RED-NIR-GREEN false-color composite image is small, with similar shades of color (pink, light pink, and lilac) for regions of different vegetation types. The water body path visibility is subtle in the NIRSWIR-RED false-color composite image when compared to the RED-NIR-GREEN and SWIR 2-NIR-BLUE composite images. The spectral response to water is shown in black in all images, but the macrophyte and sediment visualization are lighter in the latter two, corresponding to shades of pink to black in the RED-NIR-GREEN and blue to black in the SWIR 2-NIR-BLUE false-color composite images.

For a better understanding of which sensors and band combinations obtained the better results in the identification of wetlands and flood areas (Tab. 2). 
Table 2: Visual identification of wetlands through orbital images. Legend: $A=$ Appropriate; $N=$ Not appropriate. NSR = NIR-SWIR-RED; RNG = RED-NIR-GREEN; S2NB=SWIR 2-NIR-BLUE.

\begin{tabular}{l|l|l|l|l|l|l|l|l|l}
\hline Satellite/Sensor & \multicolumn{2}{l|}{ Landsat 8} & \multicolumn{2}{l|}{ Sentinel-2 } & \multicolumn{3}{l}{ CBERS-4 } \\
\hline Composition & NSR & RNG & S2NB & NSR & RNG & S2NB & NSR & S2NB & RNG \\
\hline Seasonality & A & A & A & A & A & A & N & N & N \\
\hline $\begin{array}{l}\text { Details of the flooded landscape } \\
\text { (Wetland and Flood Areas) }\end{array}$ & N & N & A & A & N & A & N & N & N \\
\hline
\end{tabular}

\section{DISCUSSION}

The visualization of ground cover in false-color composite images evaluated for three sites in this study revealed that the OLI (Landsat) and MSI (Sentinel-2) sensor composite images have similar photo interpretive ground cover results. Due to their higher spatial resolution, the Sentinel- $2^{\mathrm{M}}$ images were more suitable for small area analysis or largescale mapping. The Landsat 8 scenes, on the other hand, are more suited for the analysis of wider areas.

The resampling proved to be adequate for the MSI (Sentinel-2) sensor, possibly due to the different bands and spatial resolutions being imaged by the same sensor. All the composite images obtained for scenes from this sensor allow clear identification of the areas analyzed. On the other hand, the composite images generated from CBERS- $4^{\mathrm{M}}$ multi-sensor scenes proved difficult to interpret, especially regarding small areas. It is recommended to further study the multi-sensor false-color composite images of this satellite, especially with geometric and atmospheric corrections.

The gradation legends (from dry to rainy) allowed comparison among the different false-color composite images of the same satellite. Among the Landsat 8 composite images, the 7-5-2 (SWIR 2-NIR-BLUE) image shows the best results about the color distinction, ease of wetlands visualization, and differentiation of water-generated paths. For the Sentinel- $2^{\mathrm{M}}$ scenes, the same spectral band combination exhibits similar behavior, while the image generated by the 12-8-2 (SWIR 2-NIR-BLUE) band combination shows higher color contrast than the NIR-SWIR-RED and RED-NIR-GREEN composite images. Seasonal variability is evidenced in images from both the Landsat 8 and the Sentinel-2 ${ }^{\mathrm{M}}$ satellites, both in the SWIR 2-NIR-BLUE and NIR-SWIR-RED composite images, demonstrating the high potential use of both for ground cover identification in wetland studies.

It is important to highlight that the perusal of the management plan provided valuable insights for the comparative analysis of the images within the local context, serving as a reference for the photo interpretation phase.

\section{FINAL REMARKS}

This study was motivated by the popularity of wetland classification using remote sensing data and should support the advancement of wetland classification methods. The 
scientific community needs to assess historical methodological trends before deciding which approaches to take in the future. This article facilitates that analysis. However, the impact of classification on conservation, restoration, and other important social enterprises can also be extended by considering the application requirements and logistical limitations of operational mapping programs when developing classification protocols. For example, some orbital images may not be widely available, and some protocols may be impractical to implement on a regional scale, but only on a national or continental scale. Besides the methods may work well in one place of study, but not in another. This broader perspective can also help guide the development of classification protocols.

Concerning the current rates of loss of wetlands and the importance of monitoring these areas, this study contributed by revealing the potential of the analyzed sensors and the high spatial and temporal resolution available free of charge for detailed characterizations of wetlands at various levels. Given the limitations of this study, to improve the accuracy of wetland characterization and to better characterize wetland dynamics, future studies may involve more sophisticated methods for analyzing Sentinel-1 time series and additional indices or measurements of Sentinel-2 bands and Landsat-8. Also, on-site measurements for data collection data will largely contribute to the accuracy assessments of this study.

\section{ACKNOWLEDGMENTS}

This study was financed in part by the Coordenação de Aperfeiçoamento de Pessoal de Nível Superior - Brasil (CAPES) - Finance Code 001. We thank CAPES for the Master's Scholarships of Chaves, Ferreira and Silva, the PNPD CAPES scholarship of Guaraldo and the doctoral scholarship of Encina. We also thank the National Council for Scientific and Technological Development (CNPq), for the Research Productivity Scholarship (Process 304122/2015-7) of Paranhos Filho.

To CNPq for the award of a Productivity Subsidy in technological development and innovative extension granted to Normandes Matos da Silva (Process 315170/20182 ), and the financial support for the project of a remote piloted aircraft as a strategy to monitor fires and monitor the restoration ecological protection in protected areas. (Subject 441975/2018-6);

\section{REFERENCES}

Ab'saber A. N. (1988). O Pantanal Mato-Grossense e a teoria dos refúgios. Rev Bras Geog, 50(2), 9-57.

Adámoli, J. (1986). Fitogeografia do Pantanal. Anais do Simpósio sobre recursos naturais e sócio-econômicos do Pantanal. Corumbá, MS, Brasil,1. pp.90-106.

Alho, C.J.R., Schneider, M., Conceição, P.N., Vasconcellos, L.A.S., Oliveira, D.M. M. , Strussmann, C., \& Morais, R.M.G. (2011). Plano de manejo da estância ecológica SESC Pantanal. Conhecendo o Pantanal, 1, 5-7. Calheiros, D.F., \& Ferreira, C.J. (1997). Alterações limnlógicas no rio Paraguai "dequada" e o fenômeno natural de mortalidade de peixes no Pantanal matogrossense. Corumbá: Embrapa-CPAP. 
Earth Explorer. (2018a). United States Geological Survey. Landsat 8 Images, sensor OLI. Orbit 226, point 072. Acquisition Date: February 1, 2017. Accessed on June 5, 2018.

Earth Explorer. (2018b). United States Geological Survey. Landsat 8 Images, sensor OLI. Orbit 226, point 072. Acquisition Date: September 13, 2017. Accessed on June 5, 2018.

Earth Explorer. (2018c). United States Geological Survey. Landsat 8 Images, sensor OLI. Orbit 226, point 074. Acquisition Date: March 21, 2017. Accessed on June 5, 2018.

Earth Explorer. (2018d). United States Geological Survey. Landsat 8 Images, sensor OLI. Orbit 226, point 074. Acquisition Date: August 28, 2017. Accessed on June 5, 2018.

Earth Explorer. (2018e). United States Geological Survey. Landsat 8 Images, sensor OLI. Orbit 227, point 072. Acquisition Date: September 16, 2017. Accessed on June 5, 2018.

Earth Explorer. (2018f). United States Geological Survey. Landsat 8 Images, sensor OLI. Orbit 227, point 072. Acquisition Date: April 29, 2017. Accessed on June 5, 2018.

Earth Explorer. (2018g). United States Geological Survey. Sentinel 2A Images, sensor MSI. Orbit/point 21KVA. Acquisition Date: August 26, 2017. Accessed on June 5, 2018.

Earth Explorer. (2018h). United States Geological Survey. Sentinel 2A Images, sensor MSI. Orbit/point 21KVA. Acquisition Date: April 27, 2017. Accessed on June 5, 2018.

Earth Explorer. (2018i). United States Geological Survey. Sentinel 2A Images, sensor MSI. Orbit/point 21KWB. Acquisition Date: September 4, 2017. Accessed on June 5, 2018.

Earth Explorer. (2018j). United States Geological Survey. Sentinel 2A Images, sensor MSI. Orbit/point 21KWB. Acquisition Date: January 7, 2017. Accessed on June 5, 2018.

Earth Explorer. (2018k). United States Geological Survey. Sentinel 2A Images, sensor MSI. Orbit/point 21KWU. Acquisition Date: April 22, 2018. Accessed on June 5, 2018.

Earth Explorer. (20181). United States Geological Survey. Sentinel 2A Images, sensor MSI. Orbit/point 21KWU. Acquisition Date: August 26, 2017. Accessed on June 5, 2018.

Evans, T.L., \& Costa, M. (2013). Landcover classification of the Lower Nhecolândia subregion of the Brazilian Pantanal Wetlands using ALOS/PALSAR, RADARSAT-2, and ENVISAT/ASAR imagery. Remote Sensing of Environment, 128, 118-137. 10.1016/j.rse.2012.09.022

Gardner, R.C., Barchiesi, S., Beltrame, C., Finlayson, C.M., Galewski, T., Harrison, I., ... \& Walpole, M. (2015). State of the World's Wetlands and their Services to People: A compilation of recent analyses. (Ramsar Briefing,.7). Gland: Switzerland: Ramsar Convention Secretariat.

GIS Development Team. (2017). (Version 2.18.23 Las Palmas). [Software]. QGIS Geographic Information System.

Guimarães, E., Trevelin, C.C., \& Manoel, P.S. (2014). Pantanal: paisagens, flora e fauna. São Paulo: Cultura Acadêmica/ Ed. UNESP.

Guo, M., Li, J., Sheng, C., Xu, J., \& Wu, L.A. (2017). review of wetland remote sensing. Sensors, 17(4), 777. $10.3390 /$ s17040777

Hewes, L. (1951). The northern wet prairie of the United States: Nature, sources of information, and extent. Annals of the Association of American Geographers, 41(4), 307-323. 10.2307/2561071

ICMBIO. (2003). Plano de Manejo do Parque Nacional do Pantanal Matogrossense. Brasília: IBAMA. Recovered from https://www.google.com/url?sa=t\&rct=j\&q=\&esrc=s\&source=web\&cd=\&cad=rja\&uact=8\&ve $\mathrm{d}=2$ ahUKEwili7PWxrvrAhUlHrkGHQW3DUsQFjABegQIAxAB\&url=https \%3A\%2F\%2Fwww.icmbio. gov.br\%2Fportal\%2Fimages \% 2Fstories \%2Fimgs-unidades-coservacao\%2Fparna_matogrossensee. pdf\&usg=AOvVaw0Rh9mWiQ5cC-ie8UdabmFb

ICMBIO. (2018a). Mapa Temático e Dados Geoestatísticos das Unidades de Conservação Federais. Shapefile Unidades de Conservação Federais. 
ICMBIO. (2018b). RPPN Estância Ecológica SESC Pantanal. Shapefile. Accessed on June 12, 2018.

ICMBIO. (2018c). RPPN Rio negro. Shapefile.

INPE. (2018a). Divisão de Geração de Imagens. Catálogo de Imagens. CBERS-4 Images, sensor MUX e IRS. Orbit 165 point 122. Acquisition Date: April 15, 2017. Accessed on June 22, 2018.

INPE. (2018b). Divisão de Geração de Imagens. Catálogo de Imagens. CBERS-4 Images, sensor MUX e IRS. Orbit 165 point 122. Acquisition Date: August 23, 2017. Accessed on June 22, 2018.

INPE. (2018c). Divisão de Geração de Imagens. Catálogo de Imagens. CBERS-4 Images, sensor MUX e IRS. Orbit 166 point 129. Acquisition Date: May 8, 2017. Accessed on June 22, 2018.

INPE. (2018d). Divisão de Geração de Imagens. Catálogo de Imagens. CBERS-4 Images, sensor MUX e IRS. Orbit 166 point 129. Acquisition Date: Setember 15, 2017. Accessed on June 22, 2018.

INPE. (2018e). Divisão de Geração de Imagens. Catálogo de Imagens. CBERS-4 Images, sensor MUX e IRS. Orbit 167 point 120. Acquisition Date: September 12, 2017. Accessed on June 22, 2018.

INPE. (2018f). Divisão de Geração de Imagens. Catálogo de Imagens. CBERS-4 Images, sensor MUX e IRS. Orbit 167 point 120. Acquisition Date: April 8, 2018. Accessed on June 22, 2018.

Junk, W.J., \& Wantzen, K. M. (1989). The Flood Pulse Concept in River-Floodplain-Systems. Canadian Special Publications for Fisheries and Aquatic Sciences, 106(1), 110-127.

Lee, K.H., \& Lunetta, R.S. (1996). Wetland Detection Methods. In: J.G. Lyon, \& J. McCarthy (Orgs.), Wetland and Environmental Applications of GIS. (pp. 249-284). New York:.Lewis Publishers.

Machado, R.B., Silva, S.M., Pinto, E.C.T., Camargo, G., \& Ribeiro, A.P. (2009). Reserva Particular do Patrimônio Natural Fazenda Rio Negro - Plano de Manejo. Recovered from https:/ /www.google.com/url?s $\mathrm{a}=\mathrm{t} \& \mathrm{rct}=\mathrm{j} \& \mathrm{q}=\& \mathrm{esrc}=\mathrm{s} \&$ source=web\&cd=\&ved=2ahUKEwiP14Tqy7vrAhXmLLkGHdxaBSgQFjAAegQI AxAB\&url=https $\% 3 \mathrm{~A} \% 2 \mathrm{~F} \% 2 \mathrm{Fwww}$.imasul.ms.gov.br $\% 2 \mathrm{Fwp}$-content $\% 2 \mathrm{Fuploads} \% 2 \mathrm{~F} 2015 \% 2 \mathrm{~F} 06 \% 2 \mathrm{FP}$ lano-de-Manejo-RPPN-FRN-.pdf\&usg=AOvVaw2nqKstruQM27YptY8CSop _

Mioto, C.L., Albrez, E.A., \& Paranhos Filho, A.C. (2012). Contribuição à caracterização das sub-regiões do Pantanal. Rev Entre-Lugar, 3(6), 165-180.

Mitch, W.J., \& Gosselink, J.G. (2007). Wetlands. New Jersey: Wiley.

Nicholls, R.J. (2004). Coastal flooding and wetland loss in the 21st century: Changes under the SRES climate and socio-economic scenarios. Glob. Environ. Chang., 14, 69-86. 10.1016/j.gloenvcha.2003.10.007

Owen, O.S., \& Chiras, D.D. (1998). Natural Resource Conservation - Management for a Sustainable Future. New Jersey: Prentice-Hall.

Ozesmi, S.L., \& Bauer, M.E. (2002). Satellite remote sensing of wetlands. Wetlands ecology and management, 10(5), 381-402. 10.1023/ A:1020908432489

Paranhos Filho, A.C., Moreira, E.S., Oliveira, A.K.M., Pagotto, T.C.S., \& Mioto, C L. (2014). Análise da variação da cobertura do solo no Pantanal de 2003 a 2010 através de sensoriamento remoto. Engenharia Sanitária e Ambiental, 1(1), 69-76. 10.1590/S1413-41522014019010000305

Penatti, N.C. (2014). Geobotânica e fenologia da superfície terrestre no estudo da diversidade do Pantanal: uma abordagem multisensor. Tese de doutorado. Universidade de São Paulo, São Paulo, SP, Brasil. 10.11606/T.44.2014.tde-06022015-084733

Peres, P.N., Mioto, C.L., Marcato Junior, J. \& Paranhos Filho, A.C. (2016). Variação da Cobertura do Solo no Pantanal de 2000 a 2015 por Sensoriamento Remoto com Software e Dados Gratuitos. Anuário do Instituto de Geociências, 39(2), 116-123. 10.11137/2016_2_116_123

Rundquist, D., Gitelson, A.A., Derry, D., Ramirez, J., Stark, R, \& Keydan, G. (2001). Remote estimation of vegetation fraction in corn canopies. In G. Grenier, \& S. Blackmore. Proceedings of the Third European Conference on Precision Agriculture. (v 1, pp. 301-306). 
Santos, J.S., Pereira, G., Shimabukuro, Y.E., \& Rudorff, B. F. T. (2009). Identificação de áreas alagadas no bioma Pantanal-Brasil utilizando dados multitemporais Terra/MODIS. Geografia, 34, 745-755.

Data de submissão: 23/maio/2020

Data de aceite: $01 /$ set. $/ 2020$ 